\title{
29th International Conference on Radar Meteorology
}

\author{
12-16 July 1999 Queen Elizabeth Hotel Montreal, Quebec, Canada
}

\section{General Information}

The 29th International Conference on Radar Meteorology, sponsored by the American Meteorological Society and organized by the AMS Committee on Radar Meteorology, will be held 12-16 July 1999 at the Queen Elizabeth Hotel in Montreal, Quebec, Canada.

\section{Accommodations}

Meeting sessions will be held at the Queen Elizabeth Hotel (Le Reine Elizabeth) in Montreal. Room rates for meeting attendees are $\$ 142.00$ (Can) $\$ 94.00$ (U.S.) for a single room, and $\$ 162.00$ (Can) $\$ 107.00$ (U.S.) for a double room (plus tax). In order to receive the meeting rates, attendees must reserve a room under the AMS room block by 3 JUNE 1999. Reservations must be guaranteed with a one-night deposit. Reservations made after that date are on a space available basis. For reservations call: 514-861-3511; fax: 514-954-2258, or write the Queen Elizabeth Hotel, 900 Rene-Levesque Quest Blvd, Montreal, Quebec, Canada.

\section{Registration}

The AMS registration desk at the Queen Elizabeth Hotel will be open for registration on Sunday, 11 July 1999 from 5:00-7:00 P.M. and Monday through Friday, 12-16 1999 July during the hours of the conference.

All speakers/presenters and attendees must register and wear a badge for the conference. Conference registration includes: admission to all sessions, exhibits, and receptions, a program, a preprint volume, and one conference banquet ticket. See below for registration fees (must be paid in U.S. dollars)

\begin{tabular}{|l|l|l|}
\hline Attendee Type & By 5/21/99 & Between 5/22-6/18/99 and On-site \\
\hline${ }^{\circ}$ AMS Member; ${ }^{\circ}$ Speaker/Poster Presenter & $\$ 215.00$ (U.S.) & $\$ 255.00$ (U.S) \\
${ }^{\circ}$ Non-Member & $\$ 245.00$ & $\$ 285.00$ \\
${ }^{\circ}$ AMS Student Member & $\$ 95.00$ & $\$ 135.00$ \\
${ }^{\circ}$ Student Non-Member & $\$ 125.00$ & $\$ 165.00$ \\
${ }^{\circ}$ Retired AMS Member & $\$ 120.00$ & $\$ 160.00$ \\
\hline
\end{tabular}

\section{How to Register}

There are now several ways to register for this meeting:

1) Register on-line. Please see the AMS homepage, Web address http://www.ametsoc.org/AMS. From there select Conferences, Meetings and Symposia. Then select Online Conference Registration and follow the instructions.

2) Download the registration form from the AMS homepage. Refer to Web address http://www.ametsoc.org/AMS and follow these steps: a) Select Conferences, Meetings, and Symposia; b) select the Upcoming 1999 AMS Meeting; c) choose the Radar Conference; d) Download and print the registration form; and e) Send completed registrations by fax (617-742-8718; 617-723-8682) or mailed to: AMS, Radar Registration, 45 Beacon St., Boston, MA 02108.

3) If you do not have Web access, please contact the Meetings Department at 617-227-2426, ext 227 for a registration form. Completed forms must be faxed or mailed to AMS. 


\section{Registration Rates}

Preregistration fees are valid only if payment is received at AMS by 21 MAY 1999. Registration will not be processed without payment. Payment may be made by check, money order, purchase order or credit card (MasterCard/VISA American Express). Foreign checks must be payable in U.S. dollars. Registration forms received at AMS between 22 May-18 June 1999 and on-site will be processed at the higher fee. After 18 June, attendees must register at the meeting. Refunds (less a \$25 processing fee) will be granted only for cancellations received before 18 June 1999.

Confirmation of registration will be sent once your registration form has been processed at AMS Headquarters. Also, please note that AMS will not accept registration by phone.

\section{Travel Information}

Attendees may make airline reservations by calling AMS's designated travel agency or by calling the airlines directly. Fortune Travel is the official travel agency for the Montreal meeting. Airline reservations may be made with Fortune by calling 301-622-4000 or faxing 301-680-0825. Be sure to mention that you are attending the AMS Montreal meeting. Fortune staff is available to make reservations Monday thru Friday 8:00 A.M. -5:00 P.M. Eastern Standard Time (EST).

Both United Airlines and American Airlines are the official air carriers for this conference, and each will offer a $5 \%$ discount off any published fare (all rules apply) if you call their convention desks. For American Airlines, please call 800-433-1790, and mention the AN Number: 8179UL; for United Airlines, call 800-521-4041 and give the meeting tour code number: 567QG.

\section{Ground Travel}

The Queen Elizabeth Hotel, located downtown Montreal, is approximately 14 miles from the Dorval International Airport. Transportation from the airport to the hotel is provided by the Greyline Bus Service, which is available every 20 minutes between the hours of 5:00 A.M.-11:00 P.M. Reservations are not required, however, attendees must purchase tickets (\$9.25/one way; $\$ 16.75$ / round trip, per person) at the Greyline booth located in the Airport.

Taxi service to the hotel is approximately $\$ 25.00$ for per person/one way. Attendees driving from the Dorval Airport to the hotel should take Highway 20 East to Highway Ville Marie (Highway 720) into the downtown area; Exit to Guy Street at Rene-Levesque Blvd; Turn right and continue on this boulevard to 900 Rene-Levesque.

Avis is the official rental car agency for this meeting and special rates are available. Advance reservations may be made by calling AVIS at 800-331-1600. When making reservations, please mention the AMS referral number: J945229

For more information about Montreal, call 1-800-363-7777 or you can visit the Montreal Convention and Visitors Bureau Web site: http://www.tourisme-montreal.org

\section{Entry into Canada}

Upon entry into Canada, citizens or permanent residents of the U.S. must provide identification papers (originals or certified true copies only) showing their citizenship (i.e. birth, baptismal, naturalization or voter's certificates) plus one identification card containing a photo. U.S citizens do not need to provide visas or passports to visit Canada, however, passports can be used as proof of your citizenship. Permanent residents of the U.S. are advised to carry their Resident Alien Card (U.S. Form I-551). Further information can be obtained from the Canadian Embassy and Consulates.

\section{Exhibition Program}

The AMS will hold an exhibit program Monday, 12 July through Thursday, 15 July. The Exhibit Hall will open on Monday, 12 July at 3:00 P.M. and will follow with a "Welcoming Reception" (Cash Bar), from 6:00-7:00 P.M. The exhibit program will close on Thursday, 15 July at 1:30 P.M. 


\section{Radar Meteorology General Information (continued)}

\section{Exhibition Schedule}

\begin{tabular}{|c|c|c|}
\hline Monday, 12 July: & $\begin{array}{l}\text { 3:00-4:30 P.M. } \\
\text { 6:00-7:00 P.M. }\end{array}$ & $\begin{array}{l}\text { Exhibits open w/ Coffee Break } \\
\text { Welcome Reception }\end{array}$ \\
\hline Tuesday, 13 July: & $\begin{array}{l}\text { 9:00 A.M. }-1: 30 \text { P.M. } \\
\text { 1:30-3:00 P.M. } \\
\text { 3:00-5:00 P.M. }\end{array}$ & $\begin{array}{l}\text { Exhibits open w/ Coffee Break } \\
\text { Exhibits closed } \\
\text { Exhibits re-open w/Coffee Break }\end{array}$ \\
\hline Wednesday, 14 July: & $\begin{array}{l}\text { 9:00 A.M. }-1: 30 \text { P.M. } \\
\text { 1:30-3:00 P.M. } \\
\text { 3:00-5:00 P.M. }\end{array}$ & $\begin{array}{l}\text { Exhibits open w/ Coffee Break } \\
\text { Exhibits closed } \\
\text { Exhibits re-open w/Coffee Break }\end{array}$ \\
\hline Thursday, 15 July: & 9:00 A.M. $-1: 30$ P.M. & Exhibits re-open w/Coffee Break \\
\hline
\end{tabular}

\section{Reception / Conference Banquet}

An Icebreaker/Reception (cash bar) will be held on Monday, 12 July from 6:00-7:00 P.M. The conference banquet will be held on Tuesday, 13 July at 6:30 P.M. proceeded by a reception (cash bar) 5:30-6:30 P.M. One banquet ticket is included with registration. Additional banquet tickets may be purchased for $\$ 35$ (U.S.) until 10 A.M. on Monday, 12 July.

\section{Student Paper Award}

To honor the memory of Spiros Geotis, who inspired many students in his career of more than 40 years, the Spiros $G$. Geotis Prize will be awarded for the best student paper on Friday, 16 July.

\section{Coffee Breaks}

Morning and afternoon coffee breaks are scheduled, please see the program for specific times.

\section{Special Needs}

It is our sincere desire to comply fully with both the letter and the spirit of the Americans with Disabilities Act of 1990 (ADA). Attendees with special needs should call the AMS Meetings Department at 617-227-2426 ext. 227, 4-6 weeks prior to the meeting to request special arrangements. Special housing needs should be requested when hotel reservations are made. 


\title{
29th International Conference on Radar Meteorology 12-16 July 1999 Queen Elizabeth Hotel Montreal, Quebec, Canada
}

\author{
AMS NATIONAL OFFICERS \\ President: George L. Frederick, Jr. President-Elect: James F. Kimpel \\ Executive Director: Ronald D. Mc Pherson Executive Directors Emeritus: Richard E. Hallgren, Kenneth C. Spengler \\ AMS COMMITTEE ON ATMOSPHERIC RADIATION \\ Paul I. Joe, Chairperson \\ Donald W. Burgess, Timothy Crum, Frederic Fabry, Peter H. Hildebrand, \\ Cyntiha Mueller, F. Martin Ralph, Ronald E. Rinehart, and Matthias Steiner \\ PROGRAM COMMITTEE \\ Frederic Fabry, Chairperson \\ Aldo Bellon, Donald W. Burgess, Dick Doviak, Brant Foote David Hudak, Peter Meischner, Peter Ray, and Jacques Testud \\ LOCAL ORGANIZING COMMITTEE \\ Isztar Zaeadzki, Chairperson \\ Frederic Fabry
}

\section{SyNOPSIS OF SESSIONS}

SUN 11 JULY

5:00-7:00 Р.м. Conference Registration

MON 12 JULY

8:00 A.M. Conference Registration

9:00 A.M. Introductory Remarks

9:15 A.M. Session 1: Invited Paper

10:00 A.M. Coffee Break

10:30 A.M. Session 2: Convection Initiation

12:00 P.M. Lunch Break

1:30 P.M. Session 3: Retrievals

3:00- 4:30 P.M. Poster Session P1: Plans, Algorithms, Retrievals (with Coffee)

4:30 P.M. Session 4: Data Assimilation

6:00 P.M. Sessions end for the day

6:00 P.M. Reception/Cash Bar (with Poster Viewing)

TUES 13 JULY

8:15 A.M. Session 5: Invited Talk

9:00-10:30 A.M. Poster Session P2: Polarization, Data Quality, Signal and Data Processing, Retrievals, Hurricanes (with Coffee)

10:30 A.M. Session 6: Polarization

12:00 P.M. Lunch Break

1:30 P.M. Session 7A: Polarization Rainfall Measurements (Parallel with Session 7B)

1:30 P.M. Session 7B: Radar Networks (Parallel with Session $7 A)$

3:00 P.M. Coffee Break (with Poster Viewing)

4:00 P.M. $\quad$ Session 8A: Microphysics (Parallel with Session 8B)

4:00 P.M. Session 8B: Tropical Cyclones (Parallel with Session $8 \mathrm{~A})$
TUES 13 JULY

5:30 P.M. Sessions end for the day

5:30 P.M. Reception/Cash Bar

6:30 P.M. Conference Banquet

WED 14 JULY

8:15 A.M. Session 9: Invited Talk

9:00-10:30 A.M. Poster Session P3: Observations (with Coffee)

10:30 A.M. Plenary Discussion Session

12:00 P.M. Lunch Break

1:30 P.M. Session 10A: Data and Signal Processing (Parallel with Session 10B)

1:30 P.M. Session 10B: Observations of Stratiform Events (Parallel with Session 10A)

3:00 P.M. $\quad$ Coffee Break (with Poster Viewing)

4:00 P.M Session 11A: Clutter Recognition and Filtering (Parallel with Session 11B)

4:00 P.M Session 11B: Observations of Convective Events (Parallel with Session 11A)

5:30 P.M. Sessions end for the day

THUR 15 JULY

8:15 A.M. Session 12: Invited Talk

9:00-10:30 A.M. Poster Session P4: Drop Size Distributions, ZR Relationships, Rainfall Measurements (with Coffee)

10:30 A.M. Session 13A: TRMM Measurements and Validation (Parallel with Session 13B)

10:30 A.M. Session 13B: Data Interpretation and Quality (Parallel with Session 13A)

12:00 P.M. Lunch Break 


\section{Synopsis Continued}

THUR 15 JULY

1:30 P.M. Sesion 14A: Snowfall Measurements (Parallel with Session 14B)

1:30 P.M. Session 14B: Radar Systems (Parallel with Session 14A)

3:00 P.M. Coffee Break (with Poster Viewing)

4:00 P.M Session 15A: Rainfall Measurements (Parallel with Session 15B)

4:00 P.M Session 15B: Radar \& Aviation Issues (Parallel with Session 15A)

5:30 P.M. Sessions end for the day
FRI 16 JULY

8:15 A.M. Session 16A: Nowcasting (Parallel with Session 16B) 8:15 A.M. Session 16B: Scattering and Propagation (Parallel with Session 16A)

9:45 A.M. Coffee Break

10:15 A.M. Session 17: Hydrological Applications

11:45 A.M. Award of Geotis Prize and Closing Statement

12:00 P.M. Conference Ends

\section{Program}

SUN 11 JULY

5:00-7:00 P.M. CONFERENCE REGISTRATION

MON 12 JULY

\section{8:00 A.M. CONFERENCE REGISTRATION}

9:00 A.M. INTRODUCTORY REMARKS

\section{9:15-10:00 A.M. SESSION 1: INVITED PAPER}

1.1 WEATHER RADAR DEVELOPMENT IN EUROPE POST COST-73. Chris G. Collier, Univ. of Salford, Salford, Greater Manchester, UK

10:00 A.M. COFFEE BREAK

\section{0:30 A.M.-12:00 P.M. SESSION 2: CONVECTION INITIATION}

2.1 EVALUATION OF RADAR AND OTHER VARIABLES FOR THE 0-2 HR FORECAST OF THUNDERSTORMS. James W. Wilson, NCAR, Boulder, CO; and R. D. Roberts

2.2 DETERMINING KEY PARAMETERS FOR FORECASTING THUNDERSTORMS AT WHITE SAND MISSILE RANGE. Thomas R. Saxen, NCAR, Boulder, CO; and C. K. Mueller, T. Jameson, and E. Hatfield

2.3 NATIONAL CONVECTIVE WEATHER FORECAST STUDIES. Cynthia K. Mueller, NCAR, Boulder, CO; and D. Megenhardt and N. Rehak

2.4 THE EFFECT OF SMALL-SCALE MOISTURE VARIABILITY ON THUNDERSTORM INITIATION. Tammy M. Weckwerth, NCAR, Boulder, CO

2.5 IF FINE LINES FAIL, TRY GROUND TARGETS. Frederic Fabry, McGill Univ., Ste-Anne de Bellevue, PQ, Canada; and C. Creese
MON 12 JULY

\section{2:00 P.M. LUNCH BREAK}

1:30-3:00 P.M. SESSION 3: RETRIEVALS

3.1 DETERMINATION OF THE LOW LEVEL WIND STRUCTURE USING A MOVING FRAME AND SINGLE DOPPLER RADAR DATA. Yu-Chieng Liou, National Central Univ., Chung-Li, Taiwan

3.2 SINGLE-DOPPLER VELOCITY RETRIEVAL EXPERIMENTS WITH A SIMPLE 4DVAR TECHNIQUE. Alan Shapiro, CAPS/ Univ. of Oklahoma, Norman, OK; and P. Robinson, C. Levert, and J. Gao

3.3 THREE DIMENSIONAL VARIATIONAL WIND RETRIEVALS FROM SINGLE-DOPPLER RADAR. Jidong Gao, CAPS/Univ. of Oklahoma, Norman, OK; and A. Shapiro, M. Xue, and K. Droegemeier

3.4 IMPROVEMENT OF DUAL-DOPPLER ANALYSIS RETRIEVALS OF VERTICAL VELOCITY USING THE ANELASTIC VERTICAL VORTICITY EQUATION. John J. Mewes, Univ. of Oklahoma, Norman, OK; and A. Shapiro

3.5 ASSIMILATION OF BISTATIC RADAR NETWORK DATA AND THE NEAR-SURFACE INDEX OF REFRACTIVITY. Alain Caya, McGill Univ., Montreal, PQ, Canada; and S. Laroche

3.6 VELOCITY AND TEMPERATURE RETRIEVAL IN THE BOUNDARY LAYER USING DOPPLER RADAR OBSERVATIONS AND THE ADJOINT TECHNIQUE. Mei Xu, Univ. of Colorado, Boulder, CO; and J. Sun and N. A. Crook

3.7 REAL-TIME BOUNDARY LAYER WIND AND TEMPERATURE ANALYSIS USING SINGLE WSR-88D OBSERVATIONS. Juanzhen Sun, NCAR, Boulder, CO; and A. N. Crook 
MON 12 JULY

3:00-4:30 P.M. POSTER SESSION P1: PLANS, ALGORITHMS, RETRIEVALS (with Coffee)

P1.1 VISIONS FOR THE FUTURE REAL-TIME DISTRIBUTION OF WSR-88D BASE DATA. T. Crum, NOAA/NWS, Norman, OK; and K. K. Droegemeier, H. Edmon, K. Brewster, and D. Fulker

P1.2 IMPROVEMENTS TO THE HUMAN-COMPUTER INTERFACE FOR THE WSR-88D (NEXRAD) RADAR PRODUCT GENERATOR. David L. Priegnitz, NOAA/NSSL, Norman, OK; and E. Forren and $M$. Jain

P1.3 DEVELOPMENT OF MULTIPLE RADAR CAPABILITIES FOR THE OPEN SYSTEMS PRINCIPAL USER PROCESSOR (OPUP). Kurt D. Hondl, NOAA/NSSL, Norman, OK

P1.4 NEXRAD PRODUCT IMPROVEMENT:OVERVIEW OF NEXRAD OPEN SYSTEM PLANS. Robert E. Saffle, NOAA NWS, Silver Spring, MD

P1.5 UPDATE ON THE SOFTWARE DEVELOPMENT OF THE NEXRAD OPEN SYSTEMS RADAR PRODUCT GENERATOR (ORPG). Michael H. Jain, NOAA/NSSL, Norman, OK

P1.6 NEXRAD OPERATIONAL SUPPORT FACILITY STATUS ON OPEN SYSTEMS UPGRADES OF WSR-88D SYSTEM. J. Rex Reed, NOAA/OSF, Norman, OK

P1.7 NEXRAD SOFTWARE DEVELOPMENT ENVIRONMENT CHANGES DUE TO OPEN SYSTEMS. Michael J. Istok, NOAA/NWS, Silver Spring, MD

P1.8 NEXT GENERATION WSR-88D APPLICATIONS DEVELOPMENT - A CHANGE IN PARADIGM. Michael J. Istok, NOAA NWS, Silver Spring, MD; and R. E. Saffle

P1.9 THE COMMON OPERATIONS AND DEVELOPMENT ENVIRONMENT, STRUCTURE AND SYSTEM SERVICES. Thomas J. Ganger, Mitretek Systems, McLean, VA; and R. E. Saffle

P1.10 THE COMMON OPERATIONS DEVELOPMENT ENVIRONMENT: AN ENVIRONMENT FOR DEVELOPING AND TESTING HYDROMETEOROLOGICAL APPLICATIONS. Michael D. Eilts, NOAA/NSSL, Norman, OK; and J. Johnson, A. White, T. Gaynor, B. Armstrong, and M. Istok

P1.11 THE USE OF CODE (COMMON OPERATIONAL DEVELOPMENT ENVIRONMENT) AT THE NEXRAD OPERATIONAL SUPPORT FACILITY. Anderson White, NOAA/OSF, Norman, OK; and W. J. Armstrong

P1.12 INTEGRATED TERMINAL WEATHER SYSTEM (ITWS) - A SYSTEM PERSPECTIVE. James G. Wieler, Raytheon Systems Co., Sudbury, MA; and F. I. Harris
MON 12 JULY

P1.13 RECENT PROGRESS WITH RADAR NETWORKING IN SOUTH AFRICA. Deon E. Terblanche, Bethlehem Precipitation Research Project, Bethlehem, South Africa; and P. Visser, K. de Waal, M. Mittermaier, F. Stuart, D. Dicks, and F. Hiscutt

P1.14 FIRST RESULTS OF TRACE3D, A NEW TRACKING ALGORITHM FOR CONVECTIVE CELLS. Jan Handwerker, Universität Karlsruhe, Karlsruhe, Baden-Württemberg, Germany

P1.15 THUNDERSTORM TRACKING WITH RADAR IMAGE PROCESSING BASED ON MORPHOLOGICAL SKELETON MATCHING. Bernard Monnier, THOMSON-CSF AIRSYS, Bagneux, France; and F. Barbaresco, L. Defourneaux, and S. Legoupil

P1.16 CLASSIFYING AND ANALYSING PRECIPITATION CELLS BY MEANS OF FEATURE TREES. Markus Peura, Helsinki Univ. of Technology, Helsinki, Finland

P1.17 ANALYSIS OF SEVERE STORMS IN SOUTH AFRICA WITH THE STORM-STRUCTURE-SEVERITY METHOD. P. J. M. Visser, Bethlehem Precipitation Research Project, Bethlehem, South Africa

P1.18 THUNDERSTORM GUSTS NOWCASTING ONLY TROUGH THE REFLECTIVITY - SÃO PAULO RADAR PRELIMINARY EVENTS. Wando Celso Maugeri Amorim, Fundação Centro Tecnológico de Hidráulica, São Paulo, Brazil; and M. T. L. d. Barros and 0. Massambani

P1.19 NATIONAL WEATHER SERVICE COUNTY WARNING AREAS: A NEW CONCEPT IN MULTIPLE WSR-88D COVERAGE. Ryan L. Solomon, CIMMS/Univ. of Oklahoma, Norman, OK; and J. W. Conway, M. Lehmann, J. Johnson, and G. M. Gallina

P1.20 EVALUATION OF THE WSR-88D BUILD 10 TORNADO DETECTION ALGORITHM OVER SOUTHWEST VIRGINIA AND NORTHWEST NORTH CAROLINA. Kenneth A. Kostura, NOAA/NWSFO, Blacksburg, VA; and H. E. Hockenberry and S. Keighton

P1.21 A VOLUMETRIC REFLECTIVITY PARAMETER FOR THE IDENTIFICATION OF SEVERE HAIL. Arthur Witt, NOAA/ NSSL, Norman, OK

P1.22 NSSL MESOCYCLONE AND TORNADO DETECTION ALGORITHM PERFORMANCE - 10/4/98 OKLAHOMA TORNADO OUTBREAK. Patrick C. Burke, NOAA/NSSL, Norman, OK

P1.23 TECHNIQUE FOR IMPROVING WSR-88D DETECTION OF MESOCYCLONES. Rodger A. Brown, NOAANSSL, Norman, OK; and V. T. Wood 
MON 12 JULY

P1.24 PERFORMANCE AND EVALUATION OF THE DAMAGING DOWNBURST PREDICTION AND DETECTION ALGORITHM FOR BOW ECHO STORMS. Beth A. Karl, Texas A\&M Univ., College Station, TX; and M. I. Biggerstaff, T. Smith, and R. Przybylinski

P1.25 PERFORMANCE OF THE NSSL HAIL DETECTION ALGORITHM FOR MULTICELL STORMS OVER THE COASTAL SOUTHERN PLAINS. Kyle Bellue, Texas A\&M Univ., College Station, TX; and M. I. Biggerstaff and A. Witt

P1.26 DIFFERENTIATING BETWEEN ANA AND KATA COLD FRONTS USING RADAR DATA. Jenny M. Reddaway, Univ. of Salford, Salford, Greater Manchester, UK; and C. G. Collier, K. A. Tilford, P. J. Hardaker, and E. Archibald

P1.27 UPDATES TO THE MCGILL RAPID (RADAR DATA ANALYSIS, PROCESSING AND INTERACTIVE DISPLAY) SYSTEM. Aldo Bellon, J.S. Marshall Radar Observatory, Ste-Anne-deBellevue, PQ, Canada; and A. Kilambi

P1.28 SEVERE WEATHER DETECTION IN QUEBEC REGION AND ITS LIMITATIONS. Pierre Vaillancourt, AES, Saint-Laurent, $P Q$, Canada

P1.29 INTEGRATED REMOTE SENSOR DISPLAYS FOR TRAINING Brian C. Motta, CIRA/Colorado State Univ., Fort Collins, CO

P1.30 IMPACT OF RADIAL RANGE ON CLEAR AIR RADAR DERIVED DIVERGENCE PROFILES. Roberto V. Calheiros, Bauru-Engineering School, Bauru, SP, Brazil; and A. Gomes

P1.31 IMPROVING SINGLE-DOPPLER WIND RETRIEVALS WITH SECONDARY WIND FIELD DATA. Marc A. Wueest, ETH, Zürich, Switzerland; and W. Schmid and I. Zawadzki

P1.32 INTEGRATION OF UHF PROFILER INFORMATION WITH BISTATIC MEASUREMENTS. Pascal Guillemette, McGill Univ., Montreal, PQ, Canada

\section{4:30-6:00 P.M. SESSION 4: DATA ASSIMILATION}

4.1 AN ENSEMBLE STRATEGY FOR FORECASTS AT MESOGAMMA SCALES USING HIGH RESOLUTION PRECIPITATION OBSERVATIONS. V. Misra, McGill Univ., Montreal, PQ, Canada

4.2 INITIALIZATION OF A THREE-DIMENSIONAL MESOSCALE NON-HYDROSTATIC MODEL BY AIRBORNE DOPPLER RADAR DATA COLLECTED DURING THE TOGA-COARE EXPERIMENT. Thibaut Montmerle, CETP, Velizy, France; and J. L. Lafore, Y. Lemaitre, and J. L. Redelsperger

4.3 REAL-TIME MODEL INITIALIZATION USING SINGLE-DOPPLER RETRIEVED FIELDS OBTAINED FROM WSR-88D LEVEL-II DATA. Stephen S. Weygandt, CAPS/Univ. of Oklahoma, Norman, OK; and A. Shapiro, K. Brewster, K. K. Droegemeier, G. Bassett, and R. Carpenter
MON 12 JULY

4.4 CLEAR-AIR WSR-88D WIND RETRIEVALS FOR INITIALIZATION OF MESOSCALE MODELS. Christopher W. Porter, CIMMS/Univ. of Oklahoma, Norman, OK; and D. J. Stensrud and N. L. Seaman

4.5 A SIMPLE DIABATIC INITIALIZATION TECHNIQUE FOR STORM-RESOLVING MODELS USING NIDS DATA. Jason J. Levit, CAPS/Univ. of Oklahoma, Norman, OK; and K. K. Droegemeier

6:00 P.M. SESSIONS END FOR THE DAY

6:00 P.M. RECEPTION/CASH BAR (with Poster Viewing)

TUES 13 JULY

\section{8:15-9:00 A.M. SESSION 5: INVITED TALK}

5.1 REVIEW OF RANGE VELOCITY AMBIGUITY MITIGATION TECHNIQUES. R. Jeffrey Keeler, NCAR, Boulder, CO; and C. Frush and D. Zrnic

9:00-10:30 A.M. POSTER SESSION P2: POLARIZATION, DATA QUALITY, SIGNAL AND DATA PROCESSING, RETRIEVALS, HURRICANES (with Coffee)

P2.1 A SIMPLE WEATHER POLARIMETRIC RADAR FOR OPERATIONAL HAIL SUPPRESSION. XianQin Wang, Chengdu Institute of Meteorology, Chengdu, SC, China; and J. He, B. Zhu, and B. J. Chan

P2.2 ESTIMATION OF MEAN RAINDROP SHAPE FROM POLARIMETRIC RADAR MEASUREMENTS. E. Gorgucci, Istituto di Fisica dell'Atmosfera/CNR, Roma, Italy; and G. Scarchilli

P2.3 HYDROMETEOR CLASSIFICATION FROM POLARIMETRIC RADAR MEASUREMENTS AND IN-SITU VERIFICATION. Hongping Liu, Colorado State Univ., Fort Collins, CO; and V. Chandrasekar

P2.4 IDENTIFYING HYDROMETEOR TYPES IN TROPICAL CONVECTION USING TRMM GROUND-BASED POLARIMETRIC RADAR DATA. Lawrence D. Carey, Colorado State Univ., Fort Collins, CO; and S. A. Rutledge, J. Hubbert, and V. N. Bringi

P2.5 VERIFICATION OF POLARIMETRIC RADAR BASED CLOUD MICROPHYSICAL RESULTS USING AIRCRAFT OBSERVATIONS. S. M. Ellis, NCAR, Boulder, CO; and J. Vivekanandan and A. V. Ryzhkov

P2.6 HYDROMETEOR CLASSIFICATION WITH A C-BAND POLARIMETRIC RADAR. T. Keenan, BMRC, Melbourne, Vic, Australia

P2.7 IN-SITU AND MULTIPARAMETER RADAR OBSERVATIONS OF AN ISOLATED OKLAHOMA SUPERCELL AT FAR RANGE. Matthew L. Loney, NOAA/NSSL, Norman, OK; and D. S. Zrnic, A. V. Ryzhkov, and J. M. Straka 


\section{TUES 13 JULY}

P2.8 THE USE OF POLARIZATION DATA IN THE OPERATIONAL IDENTIFICATION OF HYDROMETEOR AND NON-HYDROMETEOR TARGETS. Yidi Liu, NOAA/NSSL, Norman, OK; and W. Conway, E. Brandes, D. Zrnic, A. Ryzhkov, and J. Vivekanandan

P2.9 95 GHZ REFLECTIVITY AND DIFFERENCE REFLECTIVITY (ZDP) SIGNATURES OF PRISTINE ICE CRYSTALS IN CLOUDS. Tom M. Walsh, Penn State Univ., University Park, PA; and K. Aydin

P2.10 SNOW FORMATION PROCESSES IN WINTER STORMS OVER THE MACKENZIE RIVER BASIN. David Hudak, AES, King City, ON, Canada; and B. Currie, V. Kezys, and B. Kochtubajda

P2.11 WHY HORIZONTAL POLARIZATION? Paul L. Smith, South Dakota School of Mines and Technology, Rapid City, SD; and R. J. Keeler

P2.12 A SIMPLE SIMULATOR FOR DIFFERENTIAL REFLECTIVITY. Paul L. Smith, South Dakota School of Mines and Technology, Rapid City, SD

P2.13 CONSTRUCTION AND INTERPRETATION OF S-BAND COVARIANCE MATRICES. G. Huang, Colorado State Univ., Fort Collins, $\mathrm{CO}$

P2.14 THE EFFECTS OF RECEIVER CLIPPING ON THE ESTIMATION OF DIFFERENTIAL PROPAGATION PHASE AND CORRELATION PARAMETERS. Robert J. Watson, Univ. of Bath, Bath, UK; and D. H. O. Bebbington, E. Torlaschi, and M. Chandra

P2.15 SIMULTANEOUS TRANSMISSION AND RECEPTION OF LINEAR VERTICAL AND LINEAR HORIZONTAL POLARIZATION FOR PRECIPITATION MEASUREMENT. Enrico Torlaschi, Univ. of Québec, Montreal, PQ, Canada; and Y. Gingras

P2.16 A COMPARISON BETWEEN PARAMETERS OBTAINED WITH THE CSU-CHILL RADAR FROM SIMULTANEOUS AND SWITCHED TRANSMISSION OF VERTICAL AND HORIZONTAL POLARISATION. Anthony R. Holt, Univ. of Essex, Colchester, Essex, UK; and V. Bringi and D. Brunkow

P2.17 ABSOLUTE CALIBRATION METHOD OF THE METEOROLOGICAL RADAR BY THE DUAL-WAVES OBSERVATIONS DATA. Yuri B. Pavlyukov, Central Aerological Observatory, Federal Service of the Meteorology and Environmental Monitoring, Dolgoprudny, Moscow Region, Russia; and Y. Melnichuk

P2.18 DATA QUALITY STUDY IN A BISTATIC NETWORK. Ramon de Elia, McGill Univ., Montreal, PQ, Canada

P2.19 ACCURACY IMPROVEMENT OF WIND FIELDS DERIVED FROM A BISTATIC MULTIPLE-DOPPLER RADAR NETWORK. Shinsuke Satoh, Univ. of Oklahoma, Norman, OK; and J. Wurman

\section{TUES 13 JULY}

P2.20 REAL-TIME VISUALIZATION TECHNIQUES FOR A REGIONAL RADAR VOLUME. William F. Roberts, NOAA/FSL, Boulder, $\mathrm{CO}$; and S. P. Longmore

P2.21 THE OPTIMIZATION OF WSR-88D SCANNING STRATEGIES FOR CONVECTIVE STORMS. Vincent T. Wood, NOAA/NSSL, Norman, OK; and R. A. Brown

P2.22 LOCAL APPLICATIONS OF THE WSR-88D HOURLY DIGITAL PRECIPITATION PRODUCT AT THE NATIONAL WEATHER SERVICE OFFICE IN TALLAHASSEE, FLORIDA. Andrew I. Watson, NOAA/NWS, Tallahassee, FL; and K. M. Stellman, K. J. Gould, and P. P. Dodge

P2.23 IDENTIFICATION OF WSR-88D CALIBRATION BIASES FROM TRMM RADAR REFLECTIVITY OBSERVATIONS. Emmanouil N. Anagnostou, Univ. of Connecticut, Storrs, CT; and C. Morales

P2.24 DESIGNING A MONITORING PROGRAM TO IDENTIFY AND FLAG HARDWARE-RELATED DEGRADATION OF THE ASR-9 PRECIPITATION DATA. Mark A. Isaminger, MIT Lincoln Lab, Lexington, MA; and B. A. Crowe, E. A. Proseus, and R. A. Boldi

P2.25 THE OCCURRENCE AND IMPACT OF BISTATIC COUPLING IN THE WSR-88D NETWORK. Elizabeth M. Quoetone, NOAA/OSF, Norman, OK; and D. Sirmans

P2.26 MONITORING RADAR SYSTEM PERFORMANCE AND INTEGRITY VIA THE INTERNET. James Stagliano, Jr., Enterprise Electronics Corp., Enterprise, AL

P2.27 ON THE OBJECTIVE ANALYSIS OF WEATHER RADAR DATA. R. Jeffrey Trapp, NOAA/NSSL, Boulder, CO; and C. A. Doswell

P2.28 IMPROVED POLAR TO CARTESIAN RADAR DATA TRANSFORMATIONS. Anders Henja, Swedish Meteorological and Hydrological Inst., Norrköping, Sweden; and D. B. Michelson

P2.29 A NEW RECEIVER AND SIGNAL PROCESSOR FOR THE CSU-CHILL RADAR. David A. Brunkow, Colorado State Univ., Ft. Collins, CO

P2.30 EVALUATION OF BATCH-MODE STAGGERED PRF TECHNIQUES FOR THE NOAA P-3 AIRBORNE DOPPLER RADAR. Tom R. Shepherd, NOAA/NSSL and CIMMS/Univ. of Oklahoma, Norman, OK; and D. P. Jorgensen and A. Goldstein

P2.31 AN INTEGRATED DEALIASING ALGORITHM FOR SINGLE, DUAL, AND MULTIPLE PRF DOPPLER VELOCITY DATA. Osamu Suzuki, MRI, Tsukuba, Ibaraki-ken, Japan

P2.32 SOFTWARE-BASED CANCELLATION OF CLUTTER IN THE DOPPLER SPECTRUM MEASURED BY A WIND PROFILER. Yuji Ohsaki, Kashima Space Research Center, Kashima-shi, Ibaraki, Japan; and Y. Masuda 
TUES 13 JULY

P2.33 IMPLEMENTATION OF AN AP CLUTTER ANALYSIS TOOL. Joseph VanAndel, NCAR/ATD, Boulder, CO; and C. Kessinger and D. Ecoff

P2.34 MESOCYCLONE CHARACTERISTICS OBSERVED BY THE PUERTO RICO WSR-88D IN HURRICANE HORTENSE. John E. Wright, NOAA/NWS, Miami, FL; and S. P. Bennett

P2.35 WINDFIELDS IN LANDFALLING HURRICANES FROM MULTIPLE DOPPLER RADAR DATA: THE 1998 HURRICANE SEASON. Peter P. Dodge, Jr., NOAA/HRD, Miami, FL; and J. Gamache, S. Houston, and F. D. Marks

P2.36 THE GBVTD ALGORITHM: OPERATIONAL APPLICATIONS AT THE NOAA/NWS/TROPICAL PREDICTION CENTER. Colin J. McAdie, NOAA/NHC, Miami, FL; and P. Dodge, S. T. Murillo, W. C. Lee, and F. Marks

P2.37 USING THE GBVTD TECHNIQUE IN NOWCASTING HURRICANE WIND FIELDS USING THE WSR-88D. Shirley T. Murillo, NOAA/AOML, Miami, FL; and W. C. Lee

P2.38 WIND/TEMPERATURE PROFILING RADAR AT SAMEER: A STATUS REVIEW. S. H. Damle, Society for Applied Microwave Electronics Engineering \& Research, Powai, Mumbai, India; and J. Chande, K. Tuckley, and A. Kulkarni

10:30 A.M.-12:00 P.M. SESSION 6: POLARIZATION

6.1 CONSIDERATIONS FOR WSR-88D UPGRADES TO IMPROVE RAINFALL MEASUREMENTS. Richard J. Doviak, NOAA/NSSL, Norman, OK; and V. Bringi, A. Ryzhkov, A. Zahrai, and D. Zrnic.

6.2 MODELING OF MEASURED POLARIMETRIC RADAR PARAMETERS AND ASSOCIATED PROPAGATION EFFECTS. John D. Beaver, Colorado State Univ., Fort Collins, CO; and V. N. Bringi and G. J. Huang

6.3 SLANT-LINEAR AND CIRCULAR POLARIZATIONS APPLIED TO DETECTION OF SUPERCOOLED DRIZZLE. Roger F. Reinking, NOAA/ERL/ETL, Boulder, CO; and S. Y. Matrosov, B. E. Martner, B. W. Orr, R. A. Kropfli, and B. W. Bartram

6.4 HYDROMETEOR CLASSIFICATION WITH A POLARIMETRIC RADAR FOR IMPROVED RAINFALL MEASUREMENTS AND DETECTION OF HAIL AND ELECTRICALLY CHARGED REGIONS. Alexander Ryzhkov, NOAA/NSSL, Norman, OK; and R. Lopez, R. Fulton, and D. S. Zrnic

6.5 AREAL RAINFALL ESTIMATION USING CONVENTIONAL AND POLARIMETRIC RADAR METHODS. Richard Fulton, NOAA/NWS, Silver Spring, MD; and A. Ryzhkov and D. Zrnic

12:00 P.M. LUNCH BREAK
TUES 13 JULY

1:30-3:00 P.M.

SESSION 7A: POLARIZATION RAINFALL MEASUREMENTS (Parallel with Session 7B)

7A.1 RAINDROP AXIS RATIOS FROM AIRCRAFT 2DP MEASUREMENTS IN CAPE FOR APPLICATION TO DUAL-POLARIZATION RADAR MEASUREMENTS. Kenneth V. Beard, Univ. of Illinois, Urbana, IL; and P. X. Xu, H. T. Ochs, and J. S. Naul

7A.2 THE ROLE OF RAINDROP SHAPE AND SIZE SPECTRA IN DERIVING RATES USING POLARISATION RADAR. Anthony J. Illingworth, Univ. of Reading, Reading, Berks., UK; and M. P. Johnson

7A.3 THE RAIN PROFILING ALGORITHM APPLIED TO POLARIMETRIC WEATHER RADAR. Jacques Testud, CETP-UVSQ, Vélizy, France; and E. LeBouar and T. Keenan

7A.4 ESTIMATION OF RAINFALL PARAMETERS USING KDP MEASURED BY THE C-BAND MULTIPARAMETER RADAR POLDIRAD. Martin Hagen, Deutsches Zentrum fuer Luft- und Raumfahrt (DLR), Wessling, Germany; and P. Meischner

7A.5 ESTIMATIONS OF RAINFALL PARAMETERS USING X-BAND POLARIZATION DATA DURING THE TRMM VALIDATION PROJECT. Sergey Y. Matrosov, CIRES/Univ. of Colorado, Boulder, CO; and B. E. Martner, R. A. Kropfli, and R. F. Reinking

7A.6 ASSESSMENT OF RAIN RATE ESTIMATORS BY A KU-BAND POLARIMETRIC RAIN RADAR. Toshio Iguchi, Communication Research Laboratory, Kashima, Ibaraki, Japan; and K. I. Timothy and H. Hanado

1:30-3:00 P.M. SESSION 7B: RADAR NETWORKS (Parallel with Session 7A)

7B.1 THE INTERNATIONAL RADAR NETWORK FOR THE BALTIC SEA EXPERIMENT. D. B. Michelson, SMHI, Norrköping, Sweden; and T. Andersson, C. G. Collier, Z. Dziewit, J. Koistinen, S. Overgaard, J. Riedl, and V. Zhukov

7B.2 THE HYDRAM PROJECT OF METEO-FRANCE : A QUALITYBASED APPROACH FOR QUANTITATIVE RADAR MEASUREMENTS. Jean-Luc Cheze, Météo-France, Toulouse, France

7B.3 PRELIMINARY STUDIES FOR THE DEPLOYMENT OF WEATHER RADAR NETWORK IN THE ISLAMIC REPUBLIC OF IRAN. S. A. Borghei, Iranian Meteorological Organization, Fort Collins, $\mathrm{CO}$; and Y. Golestani

7B.4 THE CANADIAN NATIONAL RADAR PROJECT. Steve Lapczak, AES, Downsview, ON, Canada; and E. Aldcroft, M. Stanley-Jones, J. Scott, P. Joe, B. Young, P. Van Rijn, M. Falla, A. Gagne, P. Ford, K. Reynolds, and D. Hudak 
TUES 13 JULY

7B.5 OPERATIONAL PROCESSING OF NORTH AMERICAN RADAR NETWORKS DATA AT THE CANADIAN METEOROLOGICAL CENTRE.. Yves Gingras, AES, Dorval, $P Q$, Canada; and Y. Gingras and R. Jones

7B.6 CENTRAL DATA COLLECTION AND A PROTOTYPE RADAR MOSAIC IN THE NATIONAL WEATHER SERVICE EASTERN REGION. Laurie G. Hermes, NOAA/NWS, Bohemia, NY; and D. H. Kitzmiller and L. C. Delemarre

7B.7 AN AUTOMATED SOFTWARE SYSTEM FOR PRODUCING COMPOSITE IMAGES FROM NETWORKED RADARS. Donald Burrows, Enterprise Electronics Corp., Enterprise, AL

3:00 P.M. $\quad$ COFFEE BREAK (with Poster Viewing)

4:00-5:30 P.M. SESSION 8A: MICROPHYSICS (Parallel with Session 8B)

8A.1 RADAR/MODEL COMPARISON OF PRECIPITATION INITATION IN TROPICAL CUMULUS CLOUDS. Harry T. Ochs III, ISWS, Champaign, IL; and N. F. Laird, R. M. Rauber, K. V. Beard, and L. J. Miller

8A.2 THE ROLE OF CHANGING CCN CONCENTRATIONS IN PRECIPITATION FORMATION USING A PARCEL AND A TRAJECTORY MODEL IN FOUR-DIMENSIONAL DOPPLER RADAR FIELDS. Marcin J. Szumowski, Univ. of Illinois and DRI, Reno, NV; and H. T. Ochs and R. M. Rauber

8A.3 MST RADAR CAN REVEAL MICROSTRUCTURE OF CLOUDS. M. K. Rama Varma Raja, Indian Institute of Tropical Meteorology, Pune, Maharashtra, India; and G. C. Asnani and P. S. Salvekar

8A.4 COMBINED WIND PROFILER/POLARIMETRIC RADAR STUDIES OF THE VERTICAL MOTION AND MICROPHYSICAL CHARACTERISTICS OF SEA BREEZE THUNDERSTORMS. Peter T May, BMRC, Melbourne, Vic., Australia; and A. Jameson, T. Keenan, P. Johnson, and W. Ecklund

8A.5 LIFECYCLE AND ELECTRICAL CHARACTERISTICS OF TROPICAL ISLAND THUNDERSTORMS. David A. Ahijevych, Colorado State Univ., Fort Collins, CO

8A.6 RADAR AND AIRCRAFT OBSERVATIONS OF MICROPHYSICAL EVOLUTION IN UPDRAFT REGIONS OF A HIGH PLAINS MULTICELLULAR THUNDERSTORM. Patrick C. Kennedy, Colorado State Univ., Ft. Collins, CO; and A. Detwiler and P. L. Smith

8A.7 RETRIEVAL OF VERTICAL WIND AND MICRO PHYSICS PARAMETERS FROM DOPPLER RADAR PROFILER SPECTRA EXCLUSIVELY. Dirk Klugmann, Institut fuer Troposphaerenforschung, Leipzig, Germany
TUES 13 JULY

4:00-5:30 P.M. SESSION 8B: TROPICAL CYCLONES (Parallel with Session 8A)

8B.1 EVOLUTION AND STRUCTURE OF TYPHOON ALEX (1987) FROM SINGLE DOPPLER RADAR OBSERVATIONS. WenChau Lee, NCAR, Boulder, CO; and B. J. D. Jou and P. L. Chang

8B.2 RADAR ANALYSIS OF A TYPHOON SPIRAL RAINBAND. Ben Jong-Dao Jou, National Taiwan Univ., Taipei, Taiwan; and P. L. Chang and W. C. Lee

8B.3 THE STRUCTURE OF TYPHOON HERB(1996) DURING ITS LANDFALL BY THE DUAL DOPPLER ANALYSIS. TaiChi Chen Wang, National Central Univ., Chung-Li, Tao-Yuan, Taiwan; and C. Tseng

8B.4 APPLICATION OF THREE-DIMENSIONAL VARIATIONAL AIRBORNE DOPPLER WIND ANALYSIS TO EASTERN PACIFIC HURRICANES OLIVIA (1994) AND GUILLERMO (1997).. John F. Gamache, NOAA/AOML/HRD, Miami, FL

8B.5 RECENT OBSERVATIONS OF THE CONVECTIVE STRUCTURE ASSOCIATED WITH LOW-LEVEL WIND MAXIMA IN THE HURRICANE EYEWALL. Michael L. Black, NOAA/ AOML/HRD, Miami, FL; and J. L. Franklin

8B.6 RECENT WSR-88D OBSERVATIONS OF HURRICANE ATMOSPHERIC BOUNDARY LAYER STRUCTURE AT LANDFALL. Frank D. Marks, Jr., NOAA/AOML/HRD, Miami, FL; and P. P. Dodge and C. Sandin

8B.7 HIGH RESOLUTION RADAR OBSERVATIONS OF HURRICANE GEORGES. Joshua Wurman, Univ. of Oklahoma, Norman, OK

8B.8 PROFILER OBSERVATIONS OF HURRICANE GEORGES. Kevin Knupp, Univ. of Alabama, Huntsville, AL; and J. Walters

8B.9 DISTRIBUTIONS OF RADAR REFLECTIVITY PROFILES AND MICROWAVE BRIGHTNESS TEMPERATURES OBSERVED IN TROPICAL CYCLONE EYEWALLS AND RAINBANDS. Daniel J. Cecil, Texas A\&M Univ., College Station, TX; and E. J. Zipser

\section{5:30 P.M. SESSIONS END FOR THE DAY \\ 5:30 P.M. RECEPTION/CASH BAR \\ 6:30 P.M. CONFERENCE BANQUET}

\section{WED 14 JULY}

\section{8:15-9:00 A.M. SESSION 9: INVITED TALK}

9.1 RADAR RETURNS FROM INSECTS: IMPLICATIONS FOR METEOROLOGICAL RADARS. Joseph R. Riley, Univ. of Greenwich, Malvern, Worcs., UK 
WED 14 JULY

9:00-10:30 A.M. POSTER SESSION P3: OBSERVATIONS (with Coffee)

P3.1 AIRBORNE DOPPLER RADAR ANALYSIS OF A LARGE, THREE-DIMENSIONAL, MESOSCALE CONVECTIVE SYSTEM. David P. Jorgensen, NOAA/NSSL, Boulder, CO; and T. R. Shepherd

P3.2 RADAR CHARACTIRISTICS OF MESOSCALE CONVECTIVE SYSTEM EVOLUTION. Anatoli Starostin, Universidade Federal de Pelotas, Pelotas, RS, Brazil; and A. A. Zhelnin

P3.3 MULTIPLE DOPPLER RADAR OBSERVATION OF TROPICAL PRECIPITATION SYSTEMS IN JATMEX. Koyuru Iwanami, National Research Institute for Earth Science and Disaster Prevention, Tsukuba, Ibaraki, Japan; and M. Maki, R. Misumi, Y. Sasaki, and T. D. Keenan

P3.4 AIRBORNE DUAL DOPPLER OBSERVATIONS OF A SQUALL LINE WITH A CROF (CONVECTIVE REGION OVER A FRONT). Josh Santarpia, Texas A\&M Univ., College Station, TX; and J. Santarpia, M. I. Biggerstaff, and T. Sheperd

P3.5 MULTIPLE BOUNDARIES IN THE MESOSCALE ENVIRONMENT OF A DRYLINE AS OBSERVED BY RADAR AND AIRCRAFT. Carl E. Hane, NOAA/NSSL, Norman, OK; and T. M. Crawford, M. E. Baldwin, R. M. Rabin, and H. B. Bluestein

P3.6 A CASE STUDY ON AN ASYMMETRIC SQUALL LINE OOBSERVED AT THE KANTO PLAIN, JAPAN. Yoshiaki Sasaki, NIED, Tsukuba, Ibaraki, Japan; and M. Maki, 0. Suzuki, H. Takayama, and Y. Ogura

P3.7 FORECAST OF SQUALL LINE EVOLUTION. Anatoli Starostin, Universidade Federal de Pelotas, Pelotas, RS, Brazil

P3.8 A STUDY ON SEVERE STORM IN TAIWAN IN 1998. PayLiam Lin, National Central Univ., Chung-Li, Taiwan; and C. S. Chen, Y. F. Sheng, and H. C. Lai

P3.9 A RADAR STUDY OF THE EFFECTS OF THE ISLAND OF HAWAII ON OFFSHORE RAINBAND EVOLUTION. Jian-Jian Wang, Univ. of Illinois, Urbana, IL; and R. M. Rauber, H. T. Ochs, and R. E. Carbone

P3.10 KINEMATIC STRUCTURE OF A HEAVY SNOWBAND DETERMINED FROM ELDORA DATA. Maria C. King, Univ. of IIIInois, Urbana, IL; and R. M. Rauber, M. K. Ramamurthy, and B. F. Jewett

P3.11 A COMPARISON BETWEEN POLARIMETRIC RADAR AND WIND PROFILER OBSERVATIONS OF PRECIPITATION NEAR CLOUD BASE IN TROPICAL SHOWERS. A. R. Jameson, RJH Scientific, Inc., Alexandria, VA; and P. T. May and T. D. Keenan
WED 14 JULY

P3.12 ELECTRICAL ACTIVITY OBSERVED WITH UHF AND VHF RADARS AND AN ELECTRIC FIELD MILL AT ARECIBO,PR. Monique M. Petitdidier, CETP, Velizy, France; and P. Laroche, C. W. Ulbrich, and E. F. Campos

P3.13 CLOUD IMPACTS ON URBAN GLOW. Paul R. Desrochers, Air Force Research Laboratory, Hanscom AFB, MA; and T. Hiett and S. Luker

P3.14 35GHZ FOG AND CLOUD DETECTION RADAR USING AN INCOHERENT TRANSMITTER. Yasunobu Ohmori, Mitsubishi Electric Corp., Kamakura, Kanagawa, Japan; and T. Kirimoto, T. Wakayama, S. Watanabe, T. Matsuda, H. Hashiguchi, and S. Fukao

P3.15 A FULLY-COHERENT 94 GHZ RADAR FOR THE CHARACTERISATION OF CLOUDS. J. D. Eastment, Rutherford Appleton Laboratory, Didcot, Oxfordshire, UK

P3.16 MILLIMETER-WAVE RADAR OBSERVATIONS OF VERTICAL AIR-MOTION STRUCTURE AND EVOLUTION IN PRECIPITATION. P. Kollias, RSMAS/Univ. of Miami, Miami, FL; and B. Albrecht and R. Lhermitte

P3.17 FAIR-WEATHER CUMULI STUDIES USING A 94 GHZ DOPPLER RADAR. P. Kollias, RSMAS/Univ. of Miami, Miami, FL; and B. Albrecht and R. Lhermitte

P3.18 OBSERVATIONS OF TROPICAL CLOUD SYSTEMS WITH A MM-WAVELENGTH DOPPLER RADAR-AN OVERVIEW. Bruce Albrecht, RSMAS/Univ. of Miami, Miami, FL; and P. Kollias, R. Lhermitte, and R. Peters

P3.19 MILLIMETER-WAVE CLOUD RADAR OBSERVATIONS OF ARCTIC CLOUDINESS AND VARIABILITY OVER AN ANNUAL CYCLE DURING SHEBA. Brad W. Orr, NOAA/ETL, Boulder, CO; and T. Uttal and M. Ryan

P3.20 THE STRUCTURE OF MID- AND LOW LEVEL CLOUD FIELDS OBSERVED SIMULTANEOUSLY BY GROUNDBASED AND AIRBORNE CLOUD RADAR. Olaf Danne, GKSS Research Center, Geesthacht, Schleswig-Holstein, Germany; and D. Leon, S. Haimov, and M. Quante

P3.21 CLOUD CHARACTERISTICS FROM DUAL WAVELENGTH MM WAVELENGTH RADAR. Robin J. Hogan, Univ. of Reading, Reading, Berks., UK; and A. J. Illingworth and H. Sauvageot

P3.22 COMPARISON OF ECMWF CLOUD COVER WITH RADAR DERIVED VALUES. Robin J. Hogan, Univ. of Reading, Reading, Berks., UK; and C. Jakob and A. J. Illingworth

P3.23 CLOUD DETECTION BY RADAR AND LIDAR AT THE ARM CART SITES. Eugene Edmund Clothiaux, Penn State Univ., University Park, PA; and B. E. Martner, T. P. Ackerman, K. P. Moran, and M. A. Miller 
WED 14 JULY

P3.24 COMPARISONS OF RADAR-RADIOMETER RETRIEVALS OF STRATUS CLOUD LIQUID WATER CONTENT WITH IN-SITU MEASUREMENTS FROM AIRCRAFT. A. Shelby Frisch, CIRA/Univ. of Colorado, Boulder, $\mathrm{CO}$; and B. Martner and M. Poellot

P3.25 USING DOPPLER RADAR AND MICROWAVE RADIOMETER MEASUREMENTS FOR LIQUID WATER AND ICE CONTENT RETRIEVAL IN MIXED CLOUDS. Nicolas Gaussiat, Laboratoire d'aerologie, Toulouse, France; and H. Sauvageot, R. Hogan, and A. Illingworth

P3.26 DUAL BEAM CLOUD RADAR AND BACKSCATTERING LIDAR ON THE SAME AIBORNE PLATFORM: FIRST RESULTS. Anne Guyot, IPSL-CETP, Velizy, France; and F. Baudin, S. Haimov, P. Laborie, D. Leon, A. Pazmani, J. Pelon, J. Testud, V. Trouillet, and G. Vali

P3.27 VERTICAL PLANE VELOCITY FIELDS RETRIEVED FROM DUAL BEAM AIRBORNE DOPPLER RADAR DATA. David Leon, Univ. of Wyoming, Laramie, WY; and A. Guyot, P. Laborie, A. Pazmany, J. Pelon, J. Testud, and G. Vali

P3.28 TURBULENT CLEAR AIR BOUNDARY LAYER OBSERVATIONS WITH THE CHILBOLTON RADAR AND A TETHERED INSTRUMENTED BALLOON. Charles A. D. Kilburn, Rutherford Appleton Laboratory, Didcot, Oxfordshire, UK; and J. D. Price, P. J. Hardaker, and A. Pilditch

P3.29 CHARACTERISTICS OF THE ATMOSPHERIC BOUNDARY LAYER OBSERVED WITH A UHF WIND PROFILER EQUIPPED WITH RASS. Fanny Girard, Laboratoire d'Aérologie, Campistrous, Hautes-Pyrénées, France; and B. Bénech, B. Campistron, S. Jacoby Koaly, J. Dessens, E. Dupont, and B. Carissimo

P3.30 DOPPLER RADAR AND PROFILER MEASUREMENTS OF THE NOCTURNAL BOUNDARY LAYER. Justin Walters, Univ. of Alabama, Huntsville, AL; and K. Knupp

P3.31 VERTICAL VELOCITY IN ATMOSPHERIC BOUNDARY LAYER MEASURED WITH A C-BAND DOPPLER RADAR AND A NETWORK OF THREE WIND PROFILERS. Sandra Jacoby Koaly, Laboratoire d'Aérologie, Campistrous, France; and B. Campistron, F. Girard, B. Bénech, J. Dessens, E. Dupont, and B. Carissimo

P3.32 ON THE CHANGE IN THE VERTICAL VELOCITY STRUCTURE THROUGH THE PBL DURING THE DAYTIME DEVELOPMENT OF CUMULUS CLOUDS OVER A BOREAL FOREST. D. H. Lenschow, NCAR, Boulder, CO; and A. Frisch, B. Martner, B. Orr, and D. Fitzjarrald

P3.33 VERTICAL VELOCITY STATISTICS AS DERIVED FROM 94GHZ RADAR MEASUREMENTS. Natasha L. Miles, Penn State Univ., University Park, PA; and J. Verlinde and D. M. Babb
WED 14 JULY

P3.34 KINEMATIC AND TURBULENCE CHARACTERISTICS OF A SNOWFALL EVENT USING DOPPLER RADAR DATA. Kyung-Eak Kim, Kyungpook National Univ., Buk-Ku, Taegu, South Korea; and C. K. Lee and M. Maki

P3.35 A NEW METHOD OF MEASURING EPSILON USING DUAL WAVELENGTH RADARS. Thomas E. Van Zandt, NOAAAL, Boulder, CO; and C. Williams, W. Clark, K. Gage, and W. Ecklund

P3.36 APPLICATION OF A CONSTRAINED LINEAR INVERSION ALGORITHM FOR REMOVING TURBULENT BROADENING IN DOPPLER POWER SPECTRA. D. M. Babb, Penn State Univ., University Park, PA; and J. Verlinde

P3.37 RADAR AND PROFILER EVIDENCE FOR A NEW GENESIS MECHANISM FOR LARGE-AMPLITUDE GRAVITY WAVES. Robert M. Rauber, Univ. of Illinois, Urbana, IL; and M. K. Ramamurthy, M. Yang, and B. F. Jewett

P3.38 THE ANNUAL CYCLE OF GRAVITY WAVE ACTIVITY AT 5-20 KM FROM VHF RADAR OBSERVATIONS AT WHITE SANDS MISSILE RANGE, NEW MEXICO. Gregory D. Nastrom, St. Cloud State Univ., St. Cloud, MN; and A. R. Hansen

\section{0:30 A.M.-12:00 P.M. PLENARY DISCUSSION SESSION 12:00 P.M. LUNCH BREAK}

1:30-3:00 P.M. SESSION 10A: DATA AND SIGNAL PROCESSING (Parallel with Session 10B)

10A.1 RADAR RANGENELOCITY AMBIGUITY REDUCTION: PERFORMANCE EVALUATION OF THE SZ(8/64) PHASE CODE ON A TESTBED WSR-88D. Charles L. Frush, NCAR, Boulder,, CO; and J. Daughenbaugh

10A.2 PROCESSING OF MILLIMETER WAVE DOPPLER RADAR SIGNALS IN LOW SIGNAL-TO-NOISE CONDITIONS. R. Lhermitte, RSMAS/Univ. of Miami, Miami, FL; and P. Kollias

10A.3 A HIGH-SPEED COHERENCY DIGITAL SIGNAL PROCESSOR (FIDELITY MONITOR). Larry Alford, Enterprise Electronics Corporation, Enterprise, AL

10A.4 PIRAQII: PC BASED RADAR IF RECEIVER/PROCESSOR OFFERS MORE THAN MIPS. Mitch Randall, NCAR, Boulder, CO

10A.5 DUAL-DOPPLER ANALYSIS OF NON-SIMULTANEOUS OBSERVATIONS. David C. Dowell, Univ. of Oklahoma, Norman, $\mathrm{OK}$; and H. B. Bluestein

10A.6 USING NIDS DATA TO CONSTRUCT A RADAR CLIMATOLOGY: A NEW TOOL FOR THE NEXT CENTURY. Julie R. Gaddy, Oklahoma Climatological Survey, Norman, OK; and K. C. Crawford 
WED 14 JULY

10A.7 INDEPENDENT SAMPLES IN RANGE AVERAGED FINITE BANDWIDTH LOG RECEIVER OUTPUTS. Orlando L. Rodriguez, Meteorological Institute of Cuba, Camaguey, Cuba

1:30-3:00 P.M. SESSION 10B: OBSERVATIONS OF STRATIFORM EVENTS (Parallel with Session 10A)

10B.1 EIGHT SEASONS OF DOPPLER RADAR OBSERVATIONS OF FREEZING PRECIPITATION IN TORONTO, CANADA. Norman Donaldson, Environment Canada, King City, ON, Canada

10B.2 NEXRAD SYNTHETIC DUAL-DOPPLER VELOCITY RETRIEVAL:STRUCTURE AND EVOLUTION OF A MESOSCALE LAKE-EFFECT VORTEX. Neil F. Laird, ISWS, Champaign, IL; and L. J. Miller and D. A. R. Kristovich

10B.3 ELDORA OBSERVATIONS AND NUMERICAL SIMULATIONS OF LAKE-EFFECT CONVECTIVE EVOLUTION ACROSS LAKE MICHIGAN. D. A. R. Kristovich, ISWS, Champaign, IL; and N. F. Laird and M. R. Hjelmfelt

10B.4 OBSERVATIONS OF NARROW COLD-FRONTAL RAINBANDS AND GRAVITY. Peter H. Hildebrand, NCAR, Boulder, CO

10B.5 MULTISCALE ANALYSIS OF FASTEX SECONDARY CYCLOGENESIS FROM AIRBORNE DOPPLER RADAR. Alain J. F. Protat, CETP, Velizy, France; and Y. T. A. Lemaitre, D. H. Bouniol, and G. G. D. Scialom

10B.6 THE HIGH RESOLUTION STRUCTURE OF TWO COLD FRONTS OBSERVED IN COLORADO BY IN-SITU INSTRUMENTS AND A SPACED ANTENNA WIND PROFILING SYSTEM. David B. Parsons, NCAR, Boulder, CO; and W. 0. J. Brown and S. A. Cohn

10B.7 CHARACTERISTICS OF SOUTH AUSTRALIAN FRONTS AS SEEN BY A VHF RADAR. Christopher Lucas, Univ. of Adelaide, Adelaide, SA, Australia; and R. A. Vincent and P. T. May

3:00 P.M.

COFFEE BREAK (with Poster Viewing)

4:00-5:30 P.M.

SESSION 11A: CLUTTER RECOGNITION AND FILTERING (Parallel with Session 11B)

11A.1 A CLUTTER FILTERING AND SPECTRAL MOMENT ESTIMATION ALGORITHM FOR DOPPLER WEATHER RADAR USING STAGGERED PRT TRANSMISSION. Mangalore Sachidananda, IIT, Kanpur, UP, India; and D. S. Zrnic

11A.2 GROUND CLUTTER REJECTION IN THE WEATHER CHANNEL OF THE NEXT GENERATION AIRPORT SURVEILLANCE RADAR (ASR-11). Paul Bieringer, MIT Lincoln Lab., Lexington, MA; and M. E. Weber, S. Troxel, N. I. Sapankevych, T. M. Scheve, and R. C. Evett
WED 14 JULY

11A.3 COMPENSATING REFLECTIVITY FOR CLUTTER FILTER BIAS IN THE WSR-88D. Scott Ellis, NCAR, Boulder, CO; and F. Pratte and C. Frush

11A.4 A FUZZY LOGIC AP CLUTTER DETECTION ALGORITHM FOR THE WSR-88D. Cathy Kessinger, NCAR, Boulder, CO; and $\mathrm{S}$. Ellis and $\mathrm{J}$. VanAndel

11A.5 IMPLEMENTATION OF NEXRAD AP CLUTTER MITIGATION SCHEME. R. Jeffrey Keeler, NCAR, Boulder, CO; and C. Kessinger, S. Ellis, and J. VanAndel

11A.6 COMPARISON AND ASSESSMENT OF RADAR DATA QUALITY CONTROL ALGORITHMS. Matthias Steiner, Princeton Univ., Princeton, NJ; and J. A. Smith, C. Kessinger, and B. S. Ferrier

11A.7 RADAR GROUND CLUTTER DELETION BY IMAGE PROCESSING: TEMPORAL GRADIENT INTEGRATION \& GEODESIC ACTIVE CONTOUR. Frederic Barbaresco, THOMSONCSF AIRSYS, Bagneux, R.P., France; and B. Monnier

11A.8 A SIMPLE ALGORITHM FOR THE REMOVAL OF ANOMALOUS PROPAGATION (AP) FROM RADAR IMAGES. Dimitrios Charalampidis, Univ. of Central Florida, Orlando, $\mathrm{FL}$; and T. Kasparis and W. L. Jones

11A.9 COMPARISON OF PRECIPITATION ESTIMATES OF AN ITALIAN (TORINO) AND A SWISS (LEMA) RADAR, USING A NETWORK OF GAUGES. Marco Gabella, Politechnico di Torino, Torino, Italy; and G. Perona, J. Joss, and G. Galli

4:00-5:30 P.M. SESSION 11B: OBSERVATIONS OF CONVECTIVE EVENTS (Parallel with Session 11A)

11B.1 LARGE DOMAIN STUDIES OF WARM SEASON PRECIPITATION EPISODES. R. E. Carbone, NCAR, Boulder, CO; and J. D. Tuttle, L. J. Miller, and S. Trier

11B.2 DYNAMICAL AND THERMODYNAMICAL STRUCTURE OF MESOSCALE CONVECTIVE SYSTEMS OBSERVED DURING TOGA-COARE. K. A. Caillault, CETP, Vélizy, France; and A. Protat and Y. Lemaître

11B.3 CONDENSATION AND PRECIPITATION RETRIEVALS IN INTENSE RAINCELLS: A TOGA-COARE CASE STUDY. Stéphane Oury, CETP, Vélizy, France; and J. Testud and X. Dou

11B.4 WIND STRUCTURE IN A SUPERCELL THUNDERSTORM AS MEASURED BY A DOPPLER-RADAR WIND PROFILER. Gregor S. Lehmiller, Univ. of Oklahoma, Norman, OK; and H. B. Bluestein, P. J. Neiman, F. M. Ralph, and W. F. Feltz

11B.5 RADAR AND LIGHTNING STRUCTURES OF THUNDERSTORMS DURING EULINOX. Hartmut Hoeller, DLR, Wessling, Germany; and P. Laroche, M. Hagen, J. Seltmann, and U. Finke 
WED 14 JULY

11B.6 FINE-SCALE OBSERVATIONS OF TORNADOES FROM THE ROTATE (RADAR OBSERVATIONS OF TORNADOES AND THUNDERSTORMS EXPERIMENT) 1998-9. Joshua Wurman, Univ. of Oklahoma, Norman, OK

11B.7 ORIGIN, MAINTENANCE AND FINE-SCALE STRUCTURE OF THE ST. VALENTINE'S DAY MESOSCALE GRAVITY WAVE OBSERVED DURING STORM-FEST. Muqun Yang, Univ. of Illinois, Urbana, IL; and R. M. Rauber and M. K. Ramamurthy

\section{5:30 P.M. SESSIONS END FOR THE DAY}

THUR 15 JULY

\section{8:15-9:00 A.M. SESSION 12: INVITED TALK}

12.1 THE TRMM PRECIPITATION RADAR: CHALLENGES AND OPPORTUNITIES. Robert Meneghini, NASAGSFC, Greenbelt, MD; and T. Iguchi, T. Kozu, K. Okamoto, and D. Atlas

9:00-10:30 A.M. POSTER SESSION P4: DROP SIZE DISTRIBUTIONS, Z-R RELATIONSHIPS, RAINFALL MEASUREMENTS (with Coffee)

P4.1 THE CONCEPT OF NORMALIZED GAMMA DISTRIBUTION TO DESCRIBE RAINDROP SPECTRA, AND ITS USE TO PARAMETERIZE RAIN RELATIONS. Xiankang Dou, CETP, Velizy, France; and J. Testud, P. Amayenc, and R. Black

P4.2 ON THE REQUIREMENT FOR NORMALIZING RSDS BASED ON THE GAMMA RSD FORMULATION AND IMPLICATIONS FOR INTERPRETING POLARIMETRIC RADAR DATA.. A. J. Illingworth, Univ. of Reading, Reading, Berks., UK; and T. Blackman

P4.3 DSD IDENTIFICATION FOLLOWING A PRE-CLASSIFICATION OF RAINFALL TYPE FROM RADAR ANALYSIS. Daniel R. Sempere-Torres, Universitat Politècnica de Catalunya, Barcelona, Spain; and R. Sánchez-Diezma, I. Zawadzki, and J. D. Creutin

P4.4 NEW INSIGHTS ONZ-R RELATIONS BASED ON THE TRMM GROUND VALIDATION DATASET. Eyal Amitai, Univ. of Maryland Baltimore and NASA/GSFC, Greenbelt, MD

P4.5 COMBINED USE OF THE TROPICAL RAINFALL MEASURING MISSION PRECIPITATION RADAR AND MICROWAVE IMAGER TO INFER DROP SIZE DISTRIBUTION CHARACTERISTICS. Nicolas Viltard, USRA, Greenbelt, MD; and N. Viltard, C. D. Kummerow, W. S. Olson, and Y. Hong

P4.6 IMPACT OF ADJUSTING RAIN RELATIONS ON RAIN PROFILING ESTIMATES FROM THE TRMM PRECIPITATION RADAR. Franck Ferreira, CETP, Velizy, France; and P. Amayenc

\section{THUR 15 JULY}

P4.7 DISTROMETER-DERIVED Z-R AND K-Z RELATIONSHIPS IN SINGAPORE AND PAPUA NEW, AND IMPLICATIONS FOR THE TRMM PRODUCTS. C. L. Wilson, Rutherford Appleton Laboratory, Didcot, Oxfordshire, UK; and J. W. F. Goddard, D. N. Ladd, and M. Thurai

P4.8 SPATIAL VARIABILITY OF RAINDROP SIZE DISTRIBUTION. Masayuki Maki, BMRC, Melbourne, Vic., Australia; and T. Keenan and Y. Sasaki

P4.9 DROP SIZE DISTRIBUTIONS MEASURED BY A 2D-VIDEODISDROMETER. COMPARISON WITH DUAL-POLARIZATION RADAR. Terry J. Schuur, NOAA/NSSL, Norman, OK; and A. V. Ryzhkov, D. S. Zrnic, and M. Schoenhuber

P4.10 NEW MEASUREMENTS OF THE RAINDROP SIZE DISTRIBUTION AND ITS IMPACT ON RADAR RAINFALL RETRIEVALS. Ali Tokay, NASA/GSFC, Greenbelt, MD; and 0. W. Thiele, A. Kruger, and W. Krajewski

P4.11 Z-R RELATIONS FROM INDEPENDENT MEASUREMENTS OF RAINDROP SIZE DISTRIBUTIONS. Edwin F. Campos, Instituto Meteorologico Nacional, San Jose, Costa Rica

P4.12 COMPARISONS OF 2-D VIDEO DISTROMETER DATA AND SBAND RADAR MEASUREMENTS. John C. Hubbert, Colorado State Univ., Ft. Collins, CO; and V. Bringi and M. Schoenhuber

P4.13 CHARACTERISATION OF DROP SIZE DISTRIBUTION IN MEDITERRANEAN CLIMATE: ANALYSIS OF THE SEASONAL VARIATIONS ON THE Z-R RELATION. Christian Salles, Laboratory for Experimental Geomorphology, Leuven, Belgium; and D. R. Sempere-Torres and J. D. Creutin

P4.14 EFFECTS OF Z-R LAW VARIATIONS ON COMPARISON OF NEXRAD RAINFALL AMOUNTS WITH DISDROMETER DATA. C. W. Ulbrich, Clemson Univ., Clemson, SC

P4.15 RADAR PROPERTIES OF TROPICAL RAIN FOUND FROM DISDROMETER DATA AT ARECIBO, PR. C. W. Ulbrich, Clemson Univ., Clemson, SC; M. Petitdidier and E. F. Campos

P4.16 RAIN FALLSPEEDS AND RATES DERIVED FROM AIRBORNE NADIR-POINTING DOPPLER RADAR MEASUREMENTS. Gerald M. Heymsfield, NASA/GSFC, Greenbelt, MD; and B. Geerts

P4.17 SIMPLIFIED METHOD FOR RAIN RATE AND Z-R RELATION ESTIMATION USING UHF WIND PROFILER. Yuichi Ohno, Communications Research Laboratory, Koganei, Tokyo, Japan; and C. R. Williams and K. S. Gage

P4.18 DSD PARAMETER RETRIEVALS FROM DOPPLER SPECTRA FROM A VERTICALLY POINTING S-BAND RADAR USING A TOTAL REFLECTIVITY CONSTRAINT. T. M. Blackman, Rutherford-Appleton Laboratory, Didcot, Oxfordshire, UK 


\section{THUR 15 JULY}

P4.19 ESTIMATION OF RAINDROP SIZE DISTRIBUTION PARAMETERS USING STATISTICAL RELATIONS BETWEEN MULTIPARAMETER RAINFALL REMOTE SENSING DATA. Toshiaki Kozu, Communications Research Laboratory, Koganei, Tokyo, Japan; and T. Iguchi, K. Shimizu, and N. Kashiwagi

P4.20 OBSERVATION OF RAIN DROP SIZE DISTRIBUTION IN A CONVECTIVE CLOUD WITH A DUAL-WAVELENGTH DUALPOLARIZATION RADAR. Nobuhiro Takahashi, NASA/GSFC, Greenbelt, MD; and R. Meneghini

P4.21 COMPARISON OF RAIN DROP SIZE DISTRIBUTIONS DEDUCED FROM PROFILERS AND SURFACE DISDROMETERS. Christopher R. Williams, NOAA/AL, Boulder, CO; and P. Johnston, W. Ecklund, K. Gage, D. Carter, R. Cifelli, A. Tokay, and Y. Ohno

P4.22 A STUDY OF EFFECTIVE DIELECTRIC CONSTANT OF ICEWATER SPHERES WHERE FRACTIONAL WATER CONTENT IS PRESCRIBED AS A FUNCTION OF RADIUS. Liang Liao, Caelum Research Corp., Greenbelt, MD; and R. Meneghini

P4.23 ESTIMATION OF RAINFALL RATE USING 35 GHZ ATTENUATION AND DIFFERENTIAL ATTENUATION: EFFECTS OF RAINDROP OSCILLATIONS, CANTING, AND SIZE DISTRIBUTION. K. Aydin, Penn State Univ., University Park, PA; and S. Daisley

P4.24 TROPICAL PRECIPITATING SYSTEMS OBSERVED WITH INDIAN MST RADAR. D. Narayana Rao, Centre for Atmospheric Sciences, Tirupati, India; and T. Narayana Rao and S. Raghavan

P4.25 OPTIMIZATION OF RADAR RAINFALL ESTIMATION USING LINE, AREA, AND VOLUME INTEGRATIONS OF GAUGE AND RADAR DATA. John E. Lane, Univ. of Central Florida, Satellite Beach, FL; and T. Kasparis and B. Muller

P4.26 COMBINED USE OF RADAR AND METEOSAT DATA TO CHARACTERIZE RAINY CLOUDS AND MEASURE PRECIPITATION AT GROUND. Valeria Donzelli, Telespazio S.p.A., Piana degli Albanesi, Palermo, Italy

P4.27 QUANTITATIVE PRECIPITATION ESTIMATES FROM A MOUNTAIN-TOP WSR-88D: DATA PRE-PROCESSING CONSIDERATIONS. Arlen W. Huggins, DRI, Reno, NV; and D. E. Kingsmill

P4.28 QUANTITATIVE PRECIPITATION ESTIMATES FROM A MOUNTAIN-TOP WSR-88D: THE 1997 NEW YEAR'S FLOOD. David E. Kingsmill, DRI, Reno, Nevada; and A. W. Huggins

P4.29 ON THE USE OF REAL-TIME RADAR RAINFALL ESTIMATES FOR FLOOD PREDICTION IN MOUNTAINOUS BASINS. Enrico Frank, Inst. of Hydrology Wallingford, Wallingford, Oxon, UK; and $\mathrm{M}$. Borga and $\mathrm{E}$. Anagnostou
THUR 15 JULY

P4.30 A COMPARISON OF NEXRAD WSR-88D RADAR ESTIMATES OF RAINFALL ACCUMULATION WITH RAIN GAUGE DATA FOR CONVECTIVE AND STRATIFORM EVENTS. Gerard E. Klazura, ANL, Andover, KS; and J. Thomale, D. Kelly, and P. Jendrowski

P4.31 THE WUHAN REGIONAL FLASH FLOOD EVENT OF 21-22 JULY 1998: ANALYSES OF RAINFALL ACCUMULATION DERIVED FROM WSR-81S. Yufa Wan, Wuhan Central Weather Service, Wuhan, Hubei, China; and H. Yang and C. Wu

10:30 A.M.-12:00 P.M. SESSION 13A: TRMM MEASUREMENTS AND VALIDATION (Parallel with Session 13B)

13A.1 PARTITIONING TROPICAL OCEANIC CONVECTIVE AND STRATIFORM RAIN. David Atlas, NASA/GSFC, Greenbelt, MD; and C. Ulbrich, F. D. Marks, R. A. Black, E. Amitai, P. T. Willis, and C. Samsury

13A.2 RADAR CHARACTERISTICS OF TROPICAL PRECIPITATION IN THE WESTERN TROPICAL PACIFIC OCEAN. Paul A. Kucera, Univ. of lowa, lowa City, IA; and W. F. Krajewski, A. Kruger, and C. Guard

13A.3 OPERATIONAL PROCESSING OF GROUND VALIDATION DATA FOR THE TROPICAL RAINFALL MEASURING MISSION. Mark S. Kulie, Univ. of Maryland, Baltimore, MD; and M. Robinson, D. A. Marks, B. S. Ferrier, D. Rosenfeld, and D. B. Wolff

13A.4 SEASONAL CHARACTERISTICS OF NON-METEOROLOGICAL RADAR REFLECTIVITY RETURNS IN EAST CENTRAL FLORIDA AND THEIR IMPACT ON TRMM GROUND VALIDATION. Michael Robinson, Univ. of Maryland, Baltimore, MD; and D. A. Marks, M. S. Kulie, and B. S. Ferrier

13A.5 STANDARD REFERENCE RAINFALL PRODUCTS USED IN THE TROPICAL RAINFALL MEASURING MISSION GROUND VALIDATION EFFORTS. David A. Marks, Univ. of Maryland, Baltimore, MD; and M. S. Kulie, M. Robinson, B. S. Ferrier, and E. Amitai

13A.6 POTENTIAL APPLICATION OF THE SURFACE REFERENCE TECHNIQUE OVER LAND AT LARGE INCIDENCE ANGLES. Lin Tian, USRA, Greenbelt, MD; and G. Heymsfield

13A.7 COMPARISON OF SATELLITE-BASED AND GROUND-BASED RADAR OBSERVATIONS OF PRECIPITATION. Steven M. Bolen, Colorado State Univ., Fort Collins, CO; and V. Chandrasekar

13A.8 EVALUATION OF TRMM PRECIPITATION RADAR RAINFALL ESTIMATES USING NEXRAD AND RAIN GAUGES IN CENTRAL AND SOUTH FLORIDA. Saswati Datta, Univ. of Central Florida, Orlando, FL; and B. Roy, L. Jones, T. Kasparis, P. S. Ray, Z. Ding, and D. Charalampidis 
THUR 15 JULY

13A.9 USE OF DOPPLER RADAR PROFILERS AS A CALIBRATION TOOL IN SUPPORT OF TRMM GROUND VALIDATION FIELD CAMPAIGNS. W. L. Ecklund, CIRES/Univ. of Colorado, Boulder, CO; and P. Johnston, D. Carter, R. Cifelli, and A. Tokay

13A.10COMPARISON OFWIND PROFILER, SCANNING RADAR, AND DISDROMETER ESTIMATES OFDROP SIZE DISTRIBUTION PARAMETERS DURING THE TRMM-TEFLUN CAMPAIGNS: PRELIMINARY RESULTS. Robert Cifelli, Univ. of Maryland and NASA/GSFC, Greenbelt, MD; and C. Williams, A. Tokay, and K. Gage

13A.11 HIGH RESOLUTION REFLECTIVITY PROFILES IN VARIOUS CONVECTIVELY GENERATED PRECIPITATION SYSTEMS. Bart Geerts, NASAVGSC and SSAI, Greenbelt, MD; and L. Tian and G. Heymsfield

10:30 A.M.-12:00 P.M. SESSION 13B: DATA INTERPRETATION AND QUALITY (Parallel with Session 13A)

13B.1 MONITORING AND ASSESSMENT OF SYSTEMATIC MEASUREMENT ERRORS IN THE NORDRAD NETWORK. Jarmo Koistinen, Finnish Meteorological Institute, Helsinki, Finland; and R. King, E. Saltikoff, and A. Harju

13B.2 ESTIMATION OF RADAR REFLECTIVITY BIASES BETWEEN OVERLAPPING METEOROLOGICAL RADARS. Sami Boustany, Univ. of Central Florida, Orlando, FL; and W. L. Jones and T. Kasparis

13B.3 DRY WEATHER VARIABILITY OF GROUND CLUTTER IN A MOUNTAINOUS REGION: APPLICATION TO THE CONTROL OF THE RADAR CALIBRATION STABILITY. Thierry Pellarin, LTHE, Grenoble, Isère, France; and G. Delrieu and J. Creutin

13B.4 OPERATIONAL USES OF VELOCITY SPECTRUM WIDTH DATA. Leslie R. Lemon, Lockheed Martin Ocean, Radar, \& Sensor Systems, Syracuse, NY

13B.5 COMPARISON OF THE EFFECTS OF WSR-88D VOLUME COVERAGE PATTERNS 11 AND 21 ON THE PERFORMANCE OF SEVERE WEATHER ALGORITHMS. Janelle M. Janish, CIMMS/Univ. of Oklahoma and NOAA/NSSL, Norman, OK

13B.6 THE QUANTITATIVE INTERPRETATION OF RADAR MEASUREMENTS: PART 2. Isztar Zawadzki, McGill Univ., Montreal, PQ, Canada; and F. Fabry, R. de Elia, A. Caya, and P. Vaillancourt

12:00 P.M. 1:30-3:00 P.M.

\section{LUNCH BREAK}

SESSION 14A: SNOWFALL MEASUREMENTS

(Parallel with Session 14B)

14A.1 MEASUREMENT OF SNOWFALL WITH RADARS IN FINLAND. Elena Saltikoff, Finnish Meteorological Institute, Helsinki, Finland; and J. Koistinen
THUR 15 JULY

14A.2 SNOWFALL ALGORITHMS FOR RADAR ESTIMATION OF PRECIPITATION. Paul L. Smith, South Dakota School of Mines \& Technology, Rapid City, SD; and A. B. Super

14A.3 AN EVALUATION OF THE PERFORMANCE OF THE SNOW ACCUMULATION ALGORITHM FOR THE WSR-88D AT NWSFO ALBANY, NY DURING THE 1997-98 WINTER SEASON. John S. Quinlan, NOAANWSFO, Albany, NY; and E. S. Sinsabaugh

14A.4 ASSESSMENT OF A REAL-TIME SNOW ACCUMULATION ALGORITHM AT RENO, NEVADA. Mary M. Cairns, NOAA NWSFO, Reno, NV; and M. Fresch and L. Osterman

14A.5 VERIFICATION OF NEXRAD SNOW ACCUMULATION ESTIMATES AT THE REYNOLDS CREEK EXPERIMENTAL WATERSHED. David H. Levinson, USDA/ARS, Boise, Idaho; and C. L. Hanson

14A.6 DRIFT OF PRECIPITATION PARTICLES DUE TO STRONG WIND SHEAR: CASE STUDIES IN SNOW WITH MCGILL S BAND RADAR. Marielle E. J. Gosset, ORSTOM, Ste Anne de Bellevue, $P Q$, Canada

1:30-3:00 P.M. SESSION 14B: RADAR SYSTEMS (Parallel with Session 14A)

14B.1 THE APPLICATION OF DOPPLER AND POLARIMETRIC TECHNIQUES TO C-BAND OPERATIONAL RADARS IN EUROPE. Paul J. Hardaker, UK Met Office, Wokingham, Berks., UK; and E. J. Archibald

14B.2 REENGINEERING MRL-5 FOR THE CUBAN WEATHER RADAR NETWORK. Marco A. Perez, Technical Development Laboratory, Camaguey, Cuba; and 0. L. Rodriguez, A. Pena, R. Naranjo, and L. Fernandez

14B.3 A C-BAND BISTATIC DOPPLER RADAR SYSTEM AT DLR OBERPFAFFENHOFEN. Martin Hagen, DLR, Wessling, Germany; P. Meischner, J. Wurman, M. Randall, and C. Burghart

14B.4 ADVANCED RADAR TECHNOLOGY TO IMPROVE AVIATION SAFETY. Jacques van Gorp, Sr., International Research Centre for Telecommunication and Radar, Delft, Netherlands

14B.5 NCAR'S MULTIPLE ANTENNA PROFILER RADAR. William O. J. Brown, NCAR, Boulder, CO; and S. Cohn, C. Martin, G. Maclean, and M. Susedik

14B.6 RECENT DEVELOPMENTS IN BOUNDARY LAYER RADAR WIND PROFILING. Stephen A. Cohn, NCAR, Boulder, CO; and W. O. J. Brown, J. Jordan, and L. Cornman

14B.7 AN S-BAND RADAR FOR CLOUD AND PRECIPITATION STUDIES. A. B. White, CIRES/Univ. of Colorado, Boulder, CO; and J. Jordan, F. M. Ralph, P. J. Neiman, and B. E. Martner 


\section{THUR 15 JULY}

14B.8 A 3 MM WAVELENGTH MOBILE DOPPLER RADAR FOR THE OBSERVATIONS OF TORNADOES. Andrew L. Pazmany, Univ. of Massachusetts, Amherst, MA; and C. T. Swift and H. B. Bluestein

3:00 P.M. COFFEE BREAK (with Poster Viewing)

4:00-5:30 P.M. SESSION 15A: RAINFALL MEASUREMENTS (Parallel with Session 15B)

15A.1 MICROPHYSICS OF THE MELTING LAYER: COMPARISON OF MODEL AND EXPERIMENTAL RESULTS. Sabine Goeke, ETH, Zeurich, Switzerland; and A. Waldvogel

15A.2 IDENTIFICATION OF THE BRIGHT-BAND THROUGH THE ANALYSIS OF VOLUMETRIC RADAR INFORMATION. Rafael Sánchez-Diezma, Universitat Politècnica de Catalunya, Barcelona, Spain; and I. Zawadzki and D. R. Sempere-Torres

15A.3 INTEGRATED MULTI-SENSOR APPROACH TO RAINFALL RATE ESTIMATE OPTIMISATION. Francesco Butini, S.M.A. Meteorological and Environmental Systems S.p.A., Firenze, Italy; and C. Ghiori, F. Prodi, F. Porcù, R. Medini, and M. Riess

15A.4 RAINGAUGE ADJUSTMENT OF RADAR MEASUREMENTS OF STRATIFORM RAINFALL USING THE PROBABILITY MATCHING METHOD. Chris G. Collier, Univ. of Salford, Salford, Greater Manchester, UK; and N. I. Fox, D. Hetherington, and P. Melbourne

15A.5 IMPROVEMENT OBTAINED WITH DIFFERENT METHODS TO CORRECT VOLUMETRIC RADAR DATA USING VERTICAL PROFILE OF REFLECTIVITY. B. Vignal, SMI, LocarnoMonti, TI, Switzerland; and J. Joss

15A.6 MESO-GAMMA REFLECTIVITY PROFILES CORRELATE WITH HORIZONTAL FEATURES AND HELP TO IMPROVE PRECIPITATION ESTIMATES. Urs Germann, SMI, LocarnoMonti, TI, Switzerland; and J. Joss

4:00-5:30 P.M. SESSION 15B: RADAR \& AVIATION ISSUES (Parallel with Session 15A)

15B.1 THE FAA TERMINAL CONVECTIVE WEATHER FORECAST PRODUCT. Marilyn M. Wolfson, MIT Lincoln Lab, Lexington, MA; and R. Hallowell, B. Forman, M. Moore, T. Cartwright, and K. Theriault

15B.2 WEATHER RADAR IMPROVEMENTS FOR SPACE LAUNCH SUPPORT. Billie F. Boyd, 45th Weather Squadron, Patrick AFB, FL

15B.3 ENHANCED AVIATION ORIENTED WEATHER RADAR PRODUCTS USED AT SOFIA AIRPORT. Dimitar H. Ivanov, Air Traffic Services Authority, Sofia, Bulgaria; and A. Weipert
THUR 15 JULY

15B.4 THE DETECTION OF CONVECTIVE TURBULENCE FROM AIRBORNE DOPPLER RADARS. Larry B. Cornman, NCAR, Boulder, CO; and R. Sharman and N. Beagley

15B.5 REAL-TIME SHORT-TERM SNOWFALL PREDICTION FOR AVIATION USING STORM TRACKING AND GAUGE-CALIBRATED RADAR DATA. Michael Dixon, NCAR, Boulder, CO; and R. Rasmussen

15B.6 ESTIMATE OF DROPLET SIZE AND LIQUID WATER CONTENT USING DUAL-FREQUENCY RADAR MEASUREMENTS FOR AIRCRAFT ICING DETECTION. J. Vivekanandan, NCAR, Boulder, Colorado; and G. Zhang and M. K. Politovich

\section{5:30 P.M. SESSIONS END FOR THE DAY}

FRI 16 JULY

8:15-9:45 A.M. SESSION 16A: NOWCASTING (Parallel with Session 16B)

16A.1 PROBABILISTIC 0-3 HOUR RAINFALL FORECASTS FROM AN EXTRAPOLATIVE-STATISTICAL TECHNIQUE UTILIZING RADAR AND SATELLITE OBSERVATIONS. David H. Kitzmiller, NOAA/NWS/TDL, Silver Spring, MD; and M. A. R. Lilly and S. D. Vibert

16A.2 NOWCASTING OVER COMPLEX OROGRAPHY WITH COTREC. Susanne Mecklenburg, ETH Hoenggerberg, Zurich, Switzerland; and J. Joss and W. Schmid

16A.3 ASSESSING THE UTILITY OF A REAL-TIME LOASSESSING THE UTILITY OF A REAL-TIME LOCAL FORECAST MODEL THROUGH COMPARISON WITH RADAR REFLECTIVITY. Edward J. Szoke, NOAA/FSL/ERL, Boulder, CO; and J. McGinley

16A.4 COASTAL LOW-LEVEL-JET MEASUREMENTS BY NEXRAD AND AN EXPERIMENTAL COASTAL PROFILER NETWORK IN A LAND-FALLING PACIFIC STORM. F. M. Ralph, NOAA/ ETL, Boulder, CO; and D. Kingsmill, P. Neiman, P. Persson, and W. Neff

16A.5 ON THE USE OF TDWR DATA AT NWS OFFICES DURING SEVERE CONVECTIVE WEATHER. Donald W. Burgess, NOAA/OSF, Norman, OK; and D. W. Sharp and R. E. Saffle

16A.6 MULTI-PARAMETER RADAR, AIRCRAFT, AND SATELLITE SIGNATURES ASSOCIATED WITH PRECIPITATION FORMATION IN COLORADO CONVECTIVE CLOUDS. Rita D. Roberts, NCAR, Boulder, CO; and D. W. Breed and P. C. Kennedy

16A.7 LIGHTNING INITIATION SIGNATURES INDICATED BY DOPPLER RADAR. Michael S. Gremillion, 45th Weather Squadron, Patrick Air Force Base, FL; and D. E. Harms 
FRI 16 JULY

8:15-9:45 A.M. SESSION 16B: SCATTERING AND PROPAGATION (Parallel with Session 16A)

16B.1 COHERENT DROPLET SCATTER IN DEVELOPING CUMULUS CLOUDS. J.S. Erkelens, International Research Centre for Telecommunications-Transmission and Radar, Delft, Netherlands; and V. Venema and H. Russchenberg

16B.2 COHERENT PARTICLE SCATTER IN THE MELTING LAYER OF PRECIPITATION. Victor Venema, Delft Univ. of Technology, Delft, Netherlands; and J. Erkelens, H. Russchenberg, and L. Ligthart

16B.3 MULTIPLE SCATTERING EFFECTS IN C-BAND POLARIMETRIC RADAR OBSERVATIONS OF INTENSE PRECIPITATION. D. H. O. Bebbington, Univ. of Essex, Colchester, Essex, UK; and $M$. Chandra and R. Watson

16B.4 A STUDY ON THE ALGORITHM TO MAKE ATTENUATION CORRECTION TO RADAR OBSERVATIONS OF RADAR REFLECTIVITY FACTOR. Zhenhui Wang, Nanjing Institute of Meteorology, Jiangsu, China; and P. Zhang

16B.5 POLARISATION ALGORITHMS TO CORRECT FOR ATTENUATION AT C-BAND. Chun-Lei Liu, Univ. of Reading, Reading, Berks., UK; and A. J. Illingworth

16B.6 RADOME INFLUENCE ON WEATHER RADAR SYSTEMS WITH EMPHASIS TO RAIN EFFECTS. Alexander Manz, Gematronik GmbH, Neuss, Nordrhein-Westfalen, Germany; and J. Handwerker

16B.7 BEAMHEIGHT STATISTICS FOR LOW ELEVATION SCANS. Paul I. Joe, AES, Downsview, ON, Canada

9:45 A.M. $\quad$ COFFEE BREAK

10:15-11:45 A.M. SESSION 17: HYDROLOGICAL APPLICATIONS
FRI 16 JULY

17.1 HYDROMET INTEGRATED RADAR EXPERIMENT (HIRE): EXPERIMENTAL SETUP AND FIRST RESULTS. Remko Uijlenhoet, Laboratoire d'etude des Transferts en Hydrologie et Environnement, Grenoble, Isere, France; and H. Andrieu, G. Austin, J. L. Cheze, I. Cluckie, J. D. Creutin, G. Delrieu, P. Deshons, R. Griffith, J. Porra, D. Sempere Torres, and D. Spagni

17.2 UTILIZING RADAR DATA TO IMPROVE STREAMFLOW FORECASTING. Keith M. Stellman, NOAA/NWS, Tallahassee, FL; and R. Garza and H. Fuelberg

17.3 IMPROVEMENTS IN THE SÃO PAULO FLOOD WARNING SYSTEM. Mario Thadeu Leme de Barros, Univ. of São Paulo, São Paulo, Brazil; and W. C. M. Amorim

17.4 RADAR MEASUREMENTS OF TROPICAL SUMMER CONVECTION:URBAN FEEDBACK ON FLASH FLOODS. Augusto J. Pereira Fo., Universidade de São Paulo, Cidade Universitária, São Paulo, Brazil

17.5 ON THE RELATIVE IMPORTANCE OF ALGORITHMS FOR ESTIMATING RAINFALL FROM RADAR TO THE MANAGEMENT OF URBAN STORM SEWER SYSTEMS. Neil I. Fox, Univ. of Salford, Salford, Greater Manchester, UK; and K. A. Tilford, C. G. Collier, D. Hetherington, and P. Melbourne

17.6 DEVELOPMENT OF A LARGE RADAR DATABASE FOR HYDROMETEOROLOGICAL STUDIES. Witold F. Krajewski, Univ. of lowa, lowa City, IA; and A. Kruger, D. Seo, and J. Breidenbach

17.7 COMPUTATION OF SOIL MOISTURE FOR THE CENTRAL U.S. REGION USING WSR-88D PRECIPITATION ESTIMATES. Nancy E. Westcott, ISWS, Champaign, IL; and K. E. Kunkel

11:45 A.M. AWARD OF GEOTIS PRIZE AND CLOSING STATEMENT 12:00 P.M. CONFERENCE ENDS 